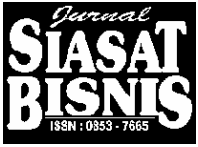

Hal.: $19-42$

\title{
PRIVATISASI: IMPLIKASINYA TERHADAP PERUBAHAN PERILAKU KARYAWAN DAN BUDAYA ORGANISASI ${ }^{*}$
}

\author{
Achmad Sobirin \\ Fakultas Ekonomi \\ Universitas Islam Indonesia
}

\begin{abstract}
Two variables are usually used as a basis to make decision of privatization. While this is not necessarily wrong, there in fact other factors that should be taken for consideration but so far being neglected. These are human and cultural factors.

This paper discusses these two factors and hypothesizes their implications in the short term and long term. In the short term, it is hypothesized that privatization will create fear, anxiety, stress and dissatisfaction among employees in which their company being privatized but no significance implication to the organizational culture. In the long term it is hypothesized that these fear, anxiety, stress and dissatisfaction will gradually be reduced. Despite this expectation, in the long term it is also expected that the success of privatization will be depending on the reaction of the people on the cultural change.
\end{abstract}

Key Words: Privatisasi, perubahan organisasi, perilaku karyawan, budaya organisasi.

\section{PENDAHULUAN}

Krisis ekonomi yang tidak berkesudahan memaksa pemerintah Indonesia menata ulang kebijakan ekonominya. Di satu sisi pemerintah berusaha maksimal mengendalikan pengeluaran-pengeluaran yang tidak perlu dalam rangka efisiensi dan di sisi lain usaha yang sama dilakukan untuk menggali sumber-sumber pendapatan baru dalam rangka menutup defisit anggaran. Salah satu alternatif penggalian sumber-sumber pendapatan adalah mengubah orientasi kegiatan pelayanan sosial layaknya menjalankan organisasi bisnis. Upaya ini biasa disebut sebagai enterprising nonprofit (Dees, 1998). Di Indonesia, rencana otonomi beberapa Perguruan Tinggi Negeri (PTN) adalah salah satu contohnya. Selain itu, yang sedang menjadi trend di negara-negara berkembang adalah menjual aset-aset negara, termasuk di dalamnya menjual badan-badan usaha milik negara (BUMN) baik sebagian maupun seluruhnya (Rama, 1999). Penjualan BUMN kepada pihak swasta inilah yang biasa disebut privatisasi.

Tentunya privatisasi bukan monopoli negara-negara berkembang seperti Indonesia, Philippines atau Thailand tetapi juga menjadi hal biasa di negara-negara maju. Cunha and Cooper (1998) misalnya melaporkan bahwa sejak tahun 1980an negara-negara Eropa mulai melaksanakan program privatisasi dalam skala yang cukup besar untuk ukuran negara maju.

*) Pernah diterbitkan pada Jurnal Siasat Bisnis edisi No. 5 Vol. 1, 2000 
Dengan merujuk pada laporan OECD- Overseas Economic Cooperation and Development, lebih lanjut dikatakan bahwa pada tahun 1995 Inggris tercatat sebagai negara paling banyak melakukan program ini. Selain di Eropa, program privatisasi juga terjadi di Amerika (lihat Thurow; 1996). Sebagai contoh, Departemen Pertahanan AS dibawah komando Menteri Pertahanan William Cohen menjalankan Defend Reform Initiative - swastanisasi kegiatan-kegiatan komersial yang ada dibawah dept. tersebut (Peters, 1999). Dalam kurun waktu 17 tahun mulai tahun 1979-1996, Peters menyatakan bahwa sebanyak 90.000 pegawai Departemen Pertahanan Amerika terpaksa harus menjadi karyawan swasta akibat program swastanisasi. Angka ini diperkirakan mencapai 230.000 pada tahun 2005. Mirsha, Spreitzer and Mirsha (1998: 83) bahkan menyebutkan bahwa sebanyak 1.1 juta orang - dihitung sejak tahun 1978, yang bekerja pada industri pertahanan Amerika terpaksa kehilangan pekerjaan akibat adanya program privatisasi dan pemotongan anggaran belanja pemerintah.

Di Indonesia sendiri, dalam beberapa tahun terakhir pemerintah mulai gencar melaksanakan program privatisasi. Keseriusan pemerintah ditunjukkan dengan dibentuknya satu departemen tersendiri, khusus untuk menangani dan member-dayakan BUMN. Pemerintah bahkan sengaja mengangkat seorang manajer profesional yang sudah malang melintang di dunia bisnis - Tanri Abeng yang diteruskan oleh Laksamana Sukardi menjadi orang nomer satu di departemen tersebut ${ }^{1}$ dengan harapan agar BUMN yang sebagian besar kinerjanya kurang menguntungkan dapat disehatkan kembali dan kemudian di swastakan. Pengga-bungan Bank Exim, BAPINDO, BBD dan BDN, menjadi Bank Mandiri, meski belum sampai tahap privatisasi, merupakan salah satu upaya penyehatan bank-bank pemerintah yang bukan tidak mungkin target berikutnya adalah menswastakan bank tersebut. Hal yang sama juga terjadi pada PT PLN yang berencana melakukan restrukturisasi dimana target berikutnya adalah merger atau aliansi strategis dengan pihak swasta - suatu kangkah awal menuju privatisasi.

Program privatisasi, baik yang terjadi di Eropa, Amerika Serikat maupun yang sedang terjadi di Indonesia, semuanya demi efisiensi dalam rangka meningkatkan daya saing, melakukan deregulasi dan peningkatan layanan kepada pelanggan, mendorong peningkatan produktivitas karyawan, memperkuat pasar modal dan membantu mengurangi beban pemerintah (Cunha and Cooper, 1998: 201). Sayangnya tujuan mulia dari privatisasi ini juga membawa efek samping yang sulit dihindarkan. Salah satunya adalah terjadinya PHK dalam jumlah yang cukup besar (Rama,

1 Sayangnya kedua manajer profesional ini pada akhirnya menempati posisi tersebut hanya dalam hitungan bulan. Laksamana Sukardi, misalnya hanya bertahan 6 bulan sebagai menteri kabinet 
1999). Jika Departemen Pertahanan Amerika harus memPHK puluhan ribu karyawan seperti contoh di atas, di Indonesia misalnya, bersamaan dengan berdirinya Bank Mandiri, ribuan karyawan sedang ditawari untuk mengikuti program pensiun dini yang notabene adalah upaya manajemen untuk merasionalisasi karyawan - kata lain dari PHK. Di samping terjadinya PHK secara besar-besaran, privatisasi juga dikhawatirkan akan mempengaruhi sikap dan prilaku karyawan yang masih tinggal, perubahan manajemen sumber daya manusia dan perubahan budaya organisasi (Cunha and Cooper, 1998). Ketiga implikasi terakhir ini sering kali luput dari perhatian karena para pengambil keputusan kadang lebih memperhatikan aspek legal dan finansial ketimbang aspek manusianya (Cartwright and Cooper, 1993a, 1993b, 1995).

Tulisan ini dimaksudkan untuk mendiskusikan implikasi dari privatisasi bukan dari aspek legal atau finansial, tetapi lebih ditekankan padai aspek manusia dan organisasi. Lebih spesifik lagi, diskusi ini akan diarahkan untuk memahami bagaimana reaksi dan sikap karyawan khususnya karyawan yang masih tinggal diperusahaan terhadap privatisasi dan bagaimana implikasinya terhadap budaya organisasi - apakah budaya organisasi yang ada cocok dengan lingkungan perusahaan yang baru, jika tidak, perubahan-perubahan apa yang perlu dilakukan.

\section{PRIVATISASI DAN PERUBAHAN ORGANISASI}

Seperti telah disinggung pada awal tulisan ini, privatisasi pada dasarnya adalah memindahkan hak pengelolaan dan atau pemilikan, sebagian atau seluruhnya, usaha-usaha milik negara kepada pihak swasta. Meski dalam dunia bisnis perubahan pengelolaan atau pemilikan perusahaan sebetulnya merupakan hal yang biasa, tidak demikian dengan privatisasi. Barangkali hal istimewa dalam privatisasi adalah alasan pemindahan tersebut bukan semata-mata alasan ekonomis tetapi kadang-kadang alasan politis atau alasan lain yang menjadi dasar utamanya. Dalam kasus privatisasi yang terjadi di Indonesia atau di Philippines dan negara-negara berkembang pada umumnya. peran IMF tampak sangat dominan (Euroweek, 1999; Rama, 1999). Artinya, kalau tidak ada desakan dari IMF bukan tidak mungkin privatisasi tersebut tidak dilakukan.

Secara umum, ada lima hal penting yang patut menjadi perhatian dalam program privatisasi yaitu: alasan ekonomi dan keuangan, informasi, strategi, pengawasan dan kultural (Cunha and Cooper, 1998: 202). Pertama, berdasarkan alasan ekonomis dan keuangan, program privatisasi diharapkan dapat membantu mengurangi defisit yang dialami perusahaanperusahaan sektor publik sehingga perusahaan ini mampu membiayai diri sendiri mengingat pemerintah sedang mengalami defisit anggaran. Dalam 
kasus privatisasi Ratchaburi - sebuah perusahaan penghasil tenaga listrik milik pemerintah Thailand yang sedang dalam tahap pembangunan, pemerintah Thailand berharap bisa menghasilkan tidak kurang dari 1.64 milyar dolar AS. Pemasukan ini diharapkan bisa digunakan untuk mengatasi masalah cash flow dan beban hutang yang dialami oleh perusahaan tersebut (lihat: East Asian Executive Reports, 1998). Di samping itu, privatisasi juga diharapkan dapat meingkatkan efisiensi dan kualitas layanan serta mengurangi keterlibatan pemerintah secara langsung dalam kegiatan bisnis.

Kedua, tujuan informatif dari privatisasi umumnya dikaitkan dengan cara pemberian insentif bagi manajer dan karyawan lainnya. Pemberian insentif bagi manajer atau karyawan perusahaan negara umumnya tidak didasarkan pada performance based tetapi didasarkan pada masa kerja, senioritas, loyalitas dan kedudukan karyawan (lihat: M. Natzir Said, 1985). Dengan cara pemberian insentif seperti ini berarti selama seorang karyawan mentaati aturan-aturan yang berlaku, tidak peduli apakah karyawan tersebut memberi kontribusi terhadap kemajuan perusahaan atau tidak, selama itu pula mereka berhak mendapatkan insentif. Demikian juga semakin lama seorang karyawan bekerja semakin tinggi pula insentif yang akan diterima. Sebaliknya, dengan privatisasi perusahaan dituntut untuk memberikan insentif bagi manajer dan karyawan berdasarkan performance based - sesuai dengan kinerja masing-masing. Untuk itu perusahaan harus efisien, baik productive efficiency (meminimalkan biaya) maupun allocative efficiency (penentuan harga jual yang merefleksikan besarnya biaya produksi). Selanjutnya agar bisa efisien, perusahaan harus mempunyai informasi yang lengkap, baik informasi pasar untuk tujuan pengukuran kinerja perusahaan maupun informasi tentang kinerja karyawan sebagai dasar pemberian insentif.

Ketiga, dalam kaitannya dengan tujuan strategis, privatisasi diharapkan dapat mengubah orientasi perusahaan menuju ke pencapaian satu tujuan yang lebih spesifik (berkonsentrasi pada core business). Perubahan orientasi ini tentu saja membutuhkan strategi perusahaan yang koheren kebalikan dari strategi perusahaan negara yang umumnya tidak terarah (disarray). Ketidakterarahan strategi perusahaan negara terjadi karena tujuan yang ingin dicapai sangat variatif, tidak konsisten dan kadang saling berlawanan. Pasal 4 ayat (1) UU no. 19 Prp 1960 misalnya, menyebutkan bahwa ada dua tujuan yang ingin dicapai Perusahaan Umum (Perum), yakni tujuan sosial dan tujuan komersial. Termasuk dalam tujuan sosial misalnya, memberi jasa dan menyelenggarakan pemanfaatan umum, membantu pemerintah dalam menciptakan lapangan kerja dan ikut mempromosikan pembangunan daerah. Di sisi lain Perum juga diharapkan dapat menghasilkan laba sebagai tujuan komersial (lihat, M. Natzir Said, 1985:18). Kedua tujuan yang saling berlawanan ini tentu saja mempersulit 
Perum dalam memformulasikan strateginya. Penelitian Cunha and Cooper (1998) pada 41 perusahaan yang berlokasi di berbagai negara menunjukkan bahwa perusahaan-perusahaan yang menjalankan privatisasi ternyata mampu meningkatkan profitabilitas dan efisiensinya. Hal ini tidak lain karena strategi yang diterapkan perusahaan-perusahaan tersebut lebih terarah dan koheren.

Keempat, dengan privatisasi berarti terjadi perubahan fungsi pengawasan perusahaan, dari pemerintah ke pihak swasta. Jika sebelumnya pemerintah mempunyai wewenang untuk menentukan siapa yang harus menjadi pimpinan puncak perusahaan, menentukan besarnya jumlah karyawan dan mengarahkan tujuan perusahaan, dengan privatisasi semua fungsi ini dikendalikan oleh pihak swasta atau paling paling tidak peranan pemerintah menjadi sangat minimal. Perubahan fungsi pengawasan ini biasanya diikuti dengan pengurangan jumlah karyawan dan adanya tuntutan agar karyawan yang tinggal bekerja lebih baik (Nijhof and Fissher, 1997). Minimal ada tiga alasan mengapa hal ini terjadi (1) setelah adanya privatisasi, posisi pemerintah dan serikat kerja sebagai alat kontrol menjadi semakin lemah (2) karena perusahaan negara cenderung padat karya dan inefisien dalam pengeloaan sumber daya manusia dan (3) dalam rangka pengurangan beban biaya gaji karyawan karena adanya over staffing.

Tujuan kelima dari privatisasi adalah menciptakan budaya perusahaan yang selaras dengan lingkungan bisnis yang baru. Sebagaimana kita ketahui, pada umumnya perusahaan negara mempunyai budaya yang sangat birokratis, kepemimpinan yang cenderung otoriter - tidak visioner, tidak inovatif, tidak efisien, sentralistik dan bahkan sering dikatakan sebagai non-komersial atau anti komersial (lihat misalnya Cunha and Cooper, 1998; Hennessey Jr., 1998; Reynolds, 1986; Pheysey, 1993). Lingkungan bisnis yang baru dengan ciri perusahaan tidak lagi bisa bertumpu pada subsidi pemerintah menuntut adanya perubahan budaya karena daya kompetitif perusahaan tidak lagi bisa mengandalkan peran pemerintah tetapi bergantung pada penilaian pasar. Jika perubahan budaya ini tidak dilakukan maka dikhawatirkan tujuan privatisasi yakni meningkatkan value of the firm tidak akan tercapai.

Dari penjelasan di atas, dapat ditarik kesimpulan sementara bahwa tema pokok dari privatisasi adalah perubahan, baik perubahan eksternal maupun perubahan internal. Sementara perubahan eksternal, terutama yang berkaitan dengan aspek ekonomi dan finansial, sudah banyak didiskusikan², tidak demikian dengan perubahan dari sisi internal. Pada dasarnya perubahan internal berkaitan dengan dua hal pokok (1) perubahan perangkat keras organisasi (hard systems tools) seperti strategi, sistem

2 The World Bank Economic Review Volume 13 No.1 misalnya berisi 7 artikel yang semuanya mendiskusikan privatisasi dari sisi ekonomi dan keuangan. 
dan struktur organisasi dan (2) perubahan perangkat lunak organisasi (soft system tools) seperti perilaku manusia dalam organisasi, kebijakan sumber daya manusia dan budaya organisasi. Bahasan berikut difokuskan pada aspek perubahan internal dari privatisasi.

\section{PERUBAHAN INTERNAL ORGANISASI}

Perubahan lingkungan internal merupakan konsekuensi dari perubahan status kepemilikan perusahaan. Ketika masih dimiliki oleh pemerintah, perusahaan dituntut untuk mencapai dua tujuan sekaligus: tujuan sosial dan komersial (Dees, 1998; M. Natzir Said, 1985). Dari kedua tujuan ini, tujuan sosial umumnya mempunyai porsi yang lebih besar ketimbang tujuan komersial. Di Indonesia, kondisi ini berlaku bagi BUMN yang berbentuk PERUM. Bagi PERJAN bahkan tidak dikenal tujuan komersial karena PERJAN merupakan bagian tak terpisahkan dari departemen pemerintah yang sifatnya philantrophic murni. Sedangkan untuk PERSERO, meski tujuan komersial lebih diutamakan, misi sosialnya tidak bisa dihilangkan sama sekali. Dengan adanya tujuan sosial berarti perusahaan tidak bisa dengan leluasa menetapkan harga jual produk/ jasanya sesuai harga pasar. Akibatnya sering terjadi pendapatan dari penjualan produk/jasa tersebut hanya bisa digunakan untuk menutup biaya operasi. Kalau akhirnya memperoleh laba, seringkali laba tersebut tidak cukup untuk reinvestasi. Oleh karena itu untuk pembiayaan jangka panjang seperti investasi, perusahaan publik cenderung mengandalkan sumber pendapatan lain yakni subsidi pemerintah. Dalam hal pemberian subsidi ini, pemerintah sendiri mempunyai kepentingan khususnya dalam rangka menjaga citra dan tujuan sosialnya. Sayangnya tujuan baik pemerintah tersebut sering disalahartikan para pengelola perusahaan publik seolah-olah kepentingan jangka panjang perusahaan adalah tanggung jawab pemerintah. Pemahaman yang salah inilah yang menjadikan subsidi, dalam batas-batas tertentu, sebagai sumber inefisiensi bagi perusahaan publik.

Setelah dimiliki oleh pihak swasta, tujuan sosial perusahaan tidak lagi menjadi prioritas utama. Kalau tidak dikatakan tidak ada, tujuan sosial tersebut sangat minimal (Fiesser, 1996). Perusahaan yang telah diswastakan lebih berorientasi pada tujuan komersial yakni memaksimumkan kekayaan pemilik (shareholder value maximization). Perubahan orientasi tujuan tersebut berakibat pada perubahan cara mengelola perusahaan utamanya karena perusahaan tidak lagi bisa bergantung pada subsidi pemerintah seperti halnya pada perusahaan negara. Oleh karenanya penjualan produk dan jasa merupakan satu-satunya sumber pendapatan agar perusahaan bisa bertahan hidup (survive) dan dari pendapatan inilah pemilik berharap kekayaannya bertambah. Dengan adanya perubahan cara 
pengelolaan berarti perusahaan harus merubah lingkungan internalnya, baik lingkungan internal yang berkaitan dengan perangkat keras perusahaan maupun perangkat lunaknya. Barlett dan Ghoshal (1994) dan Ghoshal dan Barlett (1995) mengatakan bahwa perubahan perangkat keras organisasi sering disebut perubahan struktural yang meliputi perubahan strategi, sistem dan struktur organisasi. Sedangkan perubahan pada perangkat lunak disebut sebagai perubahan kultural (Bate, 1994). Dikatakan sebagai perubahan kultural sebab proses perubahan tersebut terjadi secara gradual, berlangsung cukup lama, bisa memakan waktu beberapa tahun (Kotter and Heskett, 1992) dan melibatkan unsur manusia dan budaya organisasi (Hosftede, 1997).

Bate (1994), Cartwright and Cooper (1995) dan Wilkin and Ouchie (1983) menegaskan bahwa dalam setiap perubahan, perusahaan tidak bisa hanya memilih salah satu aspek - struktural atau kultural saja sebagai variabel yang harus diubah, tetapi kedua aspek tersebut harus dikelola secara bersamaan agar hasilnya optimal. Tentang perubahan kedua aspek ini Paul Bate (1994) menyatakan dalam ungkapan hard means soft dan soft means hard. Artinya bahwa perangkat keras dan perangkat lunak organisasi bukanlah dua variabel yang saling mengganti tetapi keduanya saling kompatibel. Meski demikian, dalam praktek para pengambil keputusan cenderung hanya memperhatikan perubahan struktural karena hasil perubahannya dapat diketahui secara langsung sementara perubahan kultural sering diabaikan karena hasil dari perubahan tersebut tidak begitu kentara. Tentang kompatibilitas kedua aspek perubahan tersebut di atas, dilukiskan pada gambar 1 berikut ini:

Gambar 1. Perangkat keras dan perangkat lunak Perusahaan dalam kaitannya dengan tujuan dan misi perusahaan

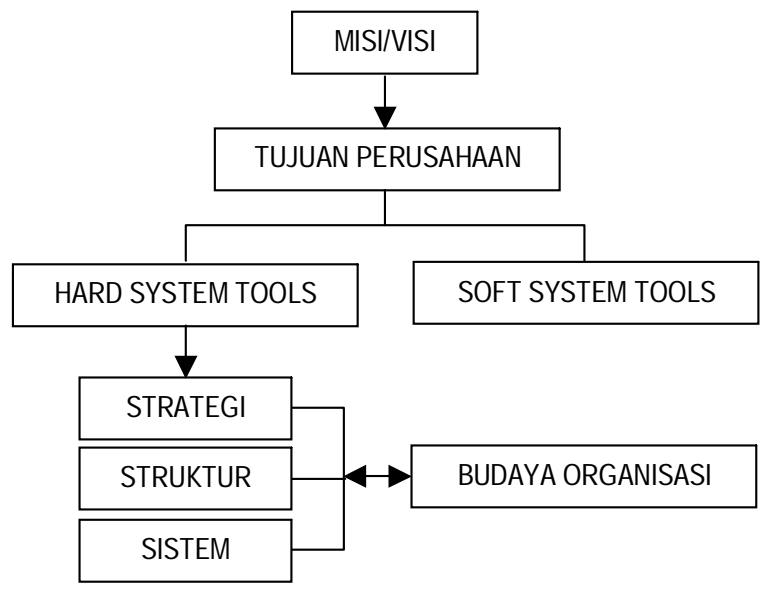


Uraian di atas menunjukkan bahwa tujuan perusahaan dapat dicapai dengan menggunakan dua perangkat yaitu perangkat keras (hard system tools) yang terdiri dari strategi, struktur dan sistem, dan perangkat lunak (soft system tools) - budaya organisasi. Ketika strategi perusahaan harus berubah karena adanya perubahan tujuan perusahaan, langsung atau tidak, perubahan ini berpengaruh terhadap sistem dan struktur organisasi perusahaan. Untuk mengakomodasi perubahan strategi, struktur organisasi lama mungkin tidak cocok lagi dengan lingkungan perusahaan yang baru dan oleh karenaya struktur organisasi tersebut juga harus dirubah (Butler, 1991). Selanjutnya, perubahan struktur organisasi ini belum memberi jaminan bahwa perusahaan bisa mencapai tujuannya secara efektif jika resistensi dari karyawan untuk melakukan perubahan sangat tinggi (Cartwright and Cooper, 1993b). Munculnya resistensi ini umumnya datang dari manajer tingkat menengah manakala perusahaan yang diprivatisasi merubah struktur organisasinya dari yang sangat hirarkis ke struktur yang flat (Cunha and Cooper, 1998). Demikian juga, perubahan strategi harus diikuti oleh perubahan budaya organisasi agar strategi tersebut bisa diimplementasikan (A. Sobirin, 1999; Bate, 1994; Wilkin and Ouchie, 1983). Penjelasan ini sekali lagi menunjukkan bahwa manakala terjadi privatisasi, maka baik perangkat keras maupun perangkat lunak organisasi, keduanya harus dirubah.

\section{IMPLIKASI PRIVATISASI TERHADAP PERUBAHAN PERILAKU KARYAWAN}

Di muka telah dijelaskan bahwa karyawan adalah pihak yang terkena dampak secara langsung ketika terjadi privatisasi. Dampak yang paling buruk adalah PHK. Pengurangan jumlah karyawan ini merupakan konsekuensi logis dari privatisasi mengingat kebiasaan perusahaan sektor publik yang cenderung padat karya dan overstaffing (Rama 1999). Di satu sisi karyawan yang tidak terkena PHK bisa dikatakan lebih beruntung sebab mereka tidak perlu bersusah payah mencari pekerjaan baru walaupun ada kemungkinan gaji mereka berkurang. Kondisi ini berlaku khususnya bagi seseorang/ masyarakat yang mempunyai tingkat penghindaran yang tinggi terhadap ketidakmenentuan - high uncertainty avoidance (Hofstede, 1980, 1997) dan menjunjung nilai-nilai keamanan keluarga (family security) sebagai pandangan hidupnya (lihat A. Sobirin, 1997). Sebagaimana dijelaskan oleh Hofstede, uncertainty avoidance adalah suatu sistem nilai dalam masyarakat yang menjunjung tinggi kepastian oleh karenanya ketidak pastian (uncertainty) harus dihindarkan. Hofstede dalam penelitiannya mengelompokkan masyarakat Indonesia sebagai masyarakat yang mempunyai tingkat uncertainty avoidance yang tinggi. Tingginya uncertainty avoidance ini disebabkan salah satunya karena sebagian besar masyara- 
kat Indonesia menempatkan keamanan keluarga sebagai orientasi hidup mereka (Sobirin, 1997). Jadi, PHK yang pada dasarnya menyebabkan seseorang menjadi tidak pasti masa depannya dan kehidupan keluarganya terganggu merupakan sesuatu yang menakutkan bagi sebagian orang Indonesia.

Meski sering dikatakan lebih beruntung, karyawan yang masih tinggal (tidak diPHK) sebetulnya tidak lebih baik ketimbang yang diPHK. Mereka justru menghadapi berbagai persoalan, baik di dalam maupun diluar pekerjaan. Persoalan ini muncul terutama karena privatisasi umumnya diikuti dengan perubahan kebijakan perusahaan seperti perubahan struktur organisasi, tujuan organisasi, teknologi dan sekaligus perubahan lingkungan kerjanya (Cunha and Cooper, 1998; Iverson, 1996; Mishra, Spreitzer and Mishra, 1998; Mesch et.al., 1999). Perubahan-perubahan tersebut pada gilirannya akan menyebabkan terjadinya perubahan kebijakan manajemen sumber daya manusia (MSDM). Sebagai contoh, jika perusahaan menerapkan kebijakan downsizing - perusahaan tidak mengganti karyawan yang diPHK, berarti karyawan yang masih tinggal harus mengerjakan pekerjaan-pekerjaan yang semula ditangani mereka yang diPHK. Bagi karyawan yang masih tinggal dengan demikian beban kerjanya bertambah dan tentunya menuntut mereka meluangkan lebih banyak waktu, dan mengeluarkan lebih banyak energi. Disamping itu tambahan pekerjaan tersebut juga secara tidak langsung mensinyalkan bahwa karyawan harus menambah ketrampilan/pengetahuan baru atau yang biasa disebut re-skilling.

Karena privatisasi cenderung berakibat pada perubahan kebijakan perusahaan, sebagaimana telah disebutkan di atas, maka ada kecenderungan pula bahwa karyawan memandang dan mensikapi perubahan tersebut dengan pandangan dan sikap negatif dan skeptis. Pandangan dan sikap negatif inilah yang menjadi pemicu dan merupakan tanda-tanda awal karyawan mengalami stress di tempat kerja (George and Jones, 1999: 303; Merch et. al., 1999). Secara definitif yang dimaksudkan dengan stress di tempat kerja (occupational stress) adalah persepsi seseorang terhadap kondisi dinamis di tempat kerja ketika menghadapi kesempatan, ancaman atau tuntutan dalam pekerjaan yang hasilnya dianggap sangat menentukan tetapi tidak pasti sehingga orang tersebut merasa tidak mampu mengatasinya secara efektif (lihat misalnya: George and Jones, 1999: 291; Robbins, 1996: 611). Berdasarkan definisi ini bisa dikatakan bahwa privatisasi merupakan sumber terjadinya stress, khususnya jika karyawan merasa bahwa kemampuan yang dimilikinya tidak sebanding dengan tuntutan pekerjaan. Definisi di atas juga menyiratkan bahwa stress pada dasarnya lebih merupakan persepsi karyawan ketimbang realitas, oleh karenanya meningkat tidaknya stress juga bergantung pada faktor lain yakni kepri- 
badian seseorang (George and Jones: 293). Karyawan dengan kepribadian Type $A$ akan mengalami stress lebih tinggi ketimbang karyawan dengan Type $B$. Hal yang sama juga akan dialami oleh karyawan dengan external locus of control dibandingkan karyawan dengan internal locus of control3.

Sejauh ini stress bisa menyebabkan karyawan mengalami gangguan fisiologis, psikologis dan perubahan prilaku (George and Jones, pp 294-297). Secara fisiologis, stress misalnya menyebabkan gangguan kesehatan. Yang paling ringan, karyawan mengalami kelelahan, atau selalu berkeringat dingin. Karyawan juga bisa mengalami depresi, meningkatnya tekanan darah atau sebaliknya menurunnya tekanan darah secara drastis, naiknya kadar gula darah dan yang lebih parah lagi bisa menyebabkan sakit jantung. Sementara itu, secara psikologis stress juga mengakibatkan karyawan menurun rasa percaya dirinya, merasa takut yang berlebihan, marah, kecewa, perasaan terhina, atau mempunyai rasa bermusuhan. Karyawan bisa juga mengalami apa yang disebut burnout - yakni kelelahan psikologis, emosi dan fisik secara berbarengan. Burnout terjadi manakala karyawan mengalami stress dalam waktu yang relatif lama yang ditandai dengan adanya perasaan depersonalisasi, rendahnya prestasi yang dicapai dan emotional exhaustion. Secara behavioral stress juga berakibat pada perubahan prilaku karyawan. Meski pada level tertentu stress memberi dampak positif yakni meningkatnya semangat kerja dan produktifitas karyawan, namun jika stress tersebut berlebihan karyawan yang semula baik, sangat ramah, suka membantu karyawan lainnya, mudah memahami orang lain atau mempunyai hubungan interpersonal yang baik bisa berakibat sebaliknya.

Untuk mengurangi/menghindari stress dan dampak negatif lain dari privatisasi, paling tidak karyawan mempunyai dua pilihan - pindah kerja atau tetap tinggal diperusahaan. Alternatif pertama hanya dimungkinkan jika karyawan mempunyai kemampuan yang memadai dan di sisi lain kesempatan kerja masih terbuka lebar. Tetapi jika tidak, suka atau tidak karyawan harus tetap tinggal di perusahaan. Repotnya, karyawan yang tetap tinggal di perusahaan akan berupaya terus untuk mengurangi dampak negatif tersebut. Dalam kasus PAM Jaya misalnya, karyawan melakukan demonstrasi sebagai bentuk penolakan terhadap privatisai perusahaan tersebut. Meski tidak dipungkiri kemungkinan adanya alasan lain (alasan politis misalnya) namun secara umum bisa dikatakan bahwa penolakan massal tersebut merupakan salah satu bentuk resistensi karyawan terhadap perubahan organisasi/privatisasi. Karyawan melakukan penolakan semacam ini kemungkinan karena: hilangnya kepercayaan mereka terha-

3 Penjelasan lengkap tentang dimensi kepribadian seseorang dapat dilihat pada Cherrington (1989: 99105) atau George and Jones (41-47) dan implikasinya terhadap stress (George and Jones: 292-294). 
dap manajemen, ketakutan karyawan terhadap ketidak menentuan masa depannya, berkurangnya pendapatan karena pemotongan gaji, masih adanya kemungkinan diPHK, terganggunya hubungan sosial kemasyarakatan, menurunnya status kepegawaian atau karena adanya ancaman-ancaman psikologis baik yang riil maupun yang hanya sekedar anggapan karyawan (lihat misalnya Iverson, 1996: 122-123; Mishra, Spreitzer, Mishra, 1998:84).

Selain dalam bentuk demonstrasi yang pada dasarnya merupakan penolakan agresif, karyawan juga akan mensikapi privatisasi dalam bentuk silent protest (protes diam-diam) seperti: frozen attitudes (sikap dingin), non-partisipatif, dan bentuk-bentuk silent protest lainnya. Bentuk penolakan diam-diam seperti ini muncul manakala karyawan tidak berani secara terbuka (karena alasan-alasan tertentu) mengemukakan ketidak setujuannya terhadap privatisasi. Dalam pemogokkan diam-diam, karyawan seperti dikatakan oleh Cherrington (1989:300) tetap bekerja seperti biasa, namun dalam menjalankan pekerjaannya karyawan hanya sekedar bekerja untuk mendapatkan nafkah dan tidak punya keinginan untuk ikut menjaga kelangsungan hidup perusahaan atau memikirkan loyalitasnya terhadap perusahaan tersebut, bahkan sabotase-sabotase kecil seringkali dilakukan oleh karyawan untuk menghambat produktifitas.

Privatisasi, dengan demikian secara fisiologis, psikologis, dan behavioral menyebabkan turunnya semangat kerja (morale) karyawan secara tajam yang tentunya akan merugikan kedua belah pihak - terhadap perusahaan dan karyawan itu sendiri. Bagi perusahaan, penuruanan semangat kerja karyawan dapat menimbulkan menurunnya kinerja perusahaan dan disisi lain penurunan semangat kerja juga berarti menurunnya kepuasan kerja karyawan.

\section{IMPLIKASI PRIVATISASI TERHADAP PERUBAHAN BUDAYA ORGANISASI}

Selain berpengaruh secara individual terhadap perubahan prilaku karyawan, privatisasi juga akan menyebabkan perubahan lingkungan organisasi, khususnya terhadap iklim dan budaya. Seperti telah disebutkan di atas, privatisasi umumnya akan dibarengi dengan perubahan budaya organisasi karena budaya yang lama sering dipandang tidak lagi kondusif dengan tatanan, lingkungan, tujuan dan misi perusahaan yang baru. Sebelum memahami lebih jauh tentang implikasi privatisasi terhadap perubahan budaya, maka terlebih dahulu akan dijelaskan pengertian budaya organisasi.

Secara anthropologis, Ashley Montagu (lihat, Poespowardojo, 1989: 219), mengatakan bahwa budaya adalah pola berpikir dan bertindak yang tercermin dalam aktivitas kehidupan manusia. Pola-pola seperti akhirnya membentuk way of life, yaitu cara hidup tertentu dari suatu 
masyarakat, yang sekaligus mencerminkan identitas masyarakat tersebut. Atau seperti yang dikatakan Christopher Dawson (Poespowardojo: ibid) culture is a common way of life - kultur sebagai cara hidup bersama. Meski pengertian ini mulanya hanya digunakan untuk membedakan way of life dari satu masyarakat dengan masyarakat yang lain, akhirnya pengertian ini diadopsi untuk membedakan satu organisasi dengan organisasi lain dengan asumsi bahwa dalam pengertian yang lebih sempit, organisasi identik dengan masyarakat.

Dalam konteks organisasi, pengertian budaya misalnya diberikan oleh Stanley Davis (1984). Davis (p.1) menyatakan:

"Budaya organisasi adalah pola keyakinan dan nilai-nilai organisasi yang dipahami, dijiwai dan dipraktekkan (shared) oleh anggota organisasi sehingga pola tersebut memberikan makna tersendiri bagi organisasi bersangkutan dan menjadi dasar aturan berperilaku didalam organisasi"

Pengertian ini memberi arti bahwa organisasi yang berbeda akan mempunyai sistem makna yang berbeda pula. Perbedaan sistem makna dari satu organisasi menyebabkan organisasi tersebut mempunyai karakteristik yang unik, berbeda dengan karakteristik organisasi lainnya (Gagliardi, 1986:119) yang pada gilirannya menjadikan sebuah organisasi mempunyai respon yang berbeda dengan organisasi lain ketika kedua organisasi tersebut menghadapi masalah yang sama. Demikian juga perbedaan sistem makna tersebut menyebabkan perbedaan prilaku para anggota organisasi dan prilaku organisasi itu sendiri.

Jika ditelusuri lebih lanjut, akar perbedaan sistem makna ini bersumber pada asumsi-asumsi dasar (kadang-kadang tidak tertulis) yang mereka gunakan untuk memecahkan persoalan organisasi (Davis, 1984; Sathe: 1985; dan Schein 1983, 1984, 1985, 1990, 1997). Termasuk dalam asumsi dasar misalnya keyakinan (beliefs), nilai-nilai (values) (Kluckhohn and Strodtbeck: 1961), filosofi atau ideologi organisasi (Leadford Jr., Wendenhof and Strahley: 1995). Schein mengatakan bahwa asumsi dasar merupakan cara yang dianggap benar, oleh karenannya cara tersebut menjadi pola dasar dalam memecahkan persoalan organisasi yang diajarkan pula kepada generasi berikutnya (anggota baru organisasi) sebagai cara yang tidak perlu lagi diperdebatkan atau dipersoalakan kebenarannya. Proses transformasi dan internalisasi asumsi dasar kedalam prilaku para

\footnotetext{
${ }_{4}^{4}$ Disini perlu ditegaskan bahwa perbedaan sistem makna tidak hanya terjadi antara satu organisasi dengan organisasi lainnya, tetapi juga bisa terjadi antara satu kelompok dengan kelompok lain yang masih dalam satu lingkup organisasi. Hal ini bisa diartikan bahwa bukan tidak mungkin dalam satu organisasi bisa dijumpai beberapa macam budaya/kultur. Pandangan ini mengaskan organisasi adalah multikultural - terdiri dari beberapa sub-kultur (lihat misalnya: Gregory: 1983; Morgan: 1986; Sobirin: 1999)
} 
anggota organisasi bisa dilakukan melalui mekanisme formal maupun informal. Secara informal, budaya organisasi bisa didiseminasi melalui ritual, cerita sukses perusahaan, upacara, mitos, maupun bahasa sehari-hari (lihat misalnya: Beyer and Trice: 1987; Martin et.al.: 1983; Martin and Powers:1993; Trice and Beyer:1984) ). Sementara itu secara formal, mekanisme dasar organisasi berikut (Cunha and Cooper, 1998) bisa dijadikan sebagai alat diseminasi:

1. Kooperasi, yakni pilihan penting antara usaha individual dan usaha kelompok,

2. Pengambilan keputusan, yakni siapa yang mempunyai kekuasaan untuk pengambilan keputusan tersebut

3. Kontrol, yakni kemampuan untuk mengambil tindakan dalam rangka mencapai tujuan yang telah ditetapkan,

4. Komunikasi, yakni pesan-pesan apa yang disampaikan dan bagaimana pesan-pesan tersebut diinterpretasikan

5. Komitmen, yakni seberapa jauh anggota organisasi mengidentifikasikan dirinya secara emosional dengan organisasi

6. Persepsi, yakni interpretasi bersama di antara para anggota organisasi terhadap pengalaman para anggota organisasi

7. Perilaku, yakni sejauh mana tindakan-tindakan para anggota organisasi dianggap benar dan memberi arti bagi organisasi.

Oleh Hofstede $(1980 ; 1983,1997)$ dan Hofstede et.al. (1990) proses internalisasi budaya seperti tersebut di atas disebut sebagai mental programming. Dari proses ini kemudian terbentuk apa yang disebut kultur/budaya organisasi yang komponennya terdiri dari Asumsi dasar, nilainilai perusahaan dan artefak (Schein: 1997). Hofstede (1997) lebih lanjut mengatakan karena adanya collective mental programming, maka kultur susah untuk berubah. Kalau toh akhirnya harus berubah, karena kultur sifatnya dinamik (Bate: 1994; Hatch: 1993; Hawkins: 1997) maka perubahan itu terjadi secara gradual. Hal ini terjadi bukan semata-mata karena kultur tersebut sudah mengendap pada pikiran masing-masing anggota organisasi, tetapi karena kultur tersebut telah terkristalisasi kedalam sistem organisasi yang telah mereka bangun bersama.

Berdasarkan pengertian ini maka dapat dijelaskan mengapa terdapat perbedaan, secara kultural, antara perusahaan publik dan perusahaan swasta dan mengapa perubahan budaya organisasi sebagai akibat adanya privatisasi susah dilakukan.

Perbedaan asumsi dasar - keyakinan, nilai-nilai, filosofi dan ideologi kedua jenis perusahaan ini, yakni perusahaan publik dengan peran sosialnya yang lebih menonjol dan perusahaan swasta dengan profit 
maximization-nya merupakan faktor utama terjadinya perbedaan kultural. Perusahaan publik, sejak semula, didirikan tidak semata-mata untuk memperoleh laba, kalau toh pada akhirnya diperoleh laba, fungsi sosial tetap saja lebih diutamakan. Dengan asumsi ini, para karyawan perusahaan publik dituntut, dilatih, dan diarahkan untuk mencapai tujuan sosial perusahaan ketimbang harus memperoleh laba optimal. Akibatnya, prilaku sosial, diharapkan, menjadi ciri dari perusahaan publik yang dalam bahasa Pheysey $^{5}$ (1993) disebut sebagai budaya dukungan (support culture). Sayangnya, dalam praktek support culture ini hanya terjadi di antara karyawan perusahaan publik, tetapi tidak terjadi dalam hubungan antara karyawan dengan pelanggannya. Penyebabnya barang kali karena perusahaan publik cenderung bersifat monopolistik sehingga fungsi layanan yang seharusnya menjadi ciri perusahaan ini berubah menjadi fungsi birokrasi dimana peranan aturan hukum dan kekuasaan para pengelola perusahaan lebih menonjol. Disinilah terjadi pergeseran dari support culture ke role culture ke power culture - budaya kekuasaan. Pengalaman penulis sendiri selama menjadi trainer pada para senior managers beberapa BUMN dan survey terhadap mereka, menunjukkan bahwa budaya kekuasaan masih mendominasi BUMN meski mereka sendiri sebetulnya tidak menghendaki itu. Sebaliknya bagi perusahaan swasta, karena orientasinya adalah laba, maka karyawan pun dituntut untuk mencapai prestasi dan berdasarkan prestasi ini pula kinerja mereka diukur. Sebab hanya dengan cara ini (memperoleh laba) perusahaan swasta bisa survive dan berkembang. Oleh karena itu achievement culture - budaya prestasi lebih merupakan ciri dari perusahaan swasta.

Penjelasan di atas sekaligus menunjukkan dan menegaskan bahwa privatisasi - perubahan dari perusahaan publik ke perusahaan swasta akan dibarengi dengan perubahan budaya. Kecenderungannya adalah berubah dari power culture ke achievement culture. Sayangnya merubah budaya bukanlah pekerjaan yang gampang (Bate, 1994; Hofstede: 1997). Dari sudut waktu, perubahan ini bisa menghabiskan 5 sampai 10 tahun (Kotter and Heskett, 1992). Itupun tingkat keberhasilannya masih dipertanyakan karena respon karyawan terhadap perubahan tersebut sangat bervariasi (Harris and Ogbona, 1998). Dalam penelitiannya, Harris and Ogbona mengatakan bahwa keberhasilan perubahan budaya, salah satunya bergantung pada kuat tidaknya kultur dan sub-kultur perusahaan yang sekarang ada 6 . Faktor lain yang berpengaruh terhadap

${ }^{5}$ Diana Pheysey (1993) menyebutkan adanya empat tipe budaya organisasi yakni Power culture budaya kekuasaan, Role culture - budaya peran, Achievement culture - budaya prestasi dan Support culture -budaya dukungan

${ }_{6}$ Untuk mengetahui pengertian strong culture (budaya yang kuat) dan weak culture (budaya yang lemah) lihat misalnya Sobirin (1999). 
keberhasilan perubahan budaya adalah kemauan para anggota organisasi untuk berpartisipasi dalam perubahan. Dari kedua faktor ini, Harris and Ogbonna mengidentifikasikan adanya sembilan kemungkinan reaksi karyawan terhadap perubahan budaya organisasi sebagaimana tampak pada gambar 2 berikut ini:

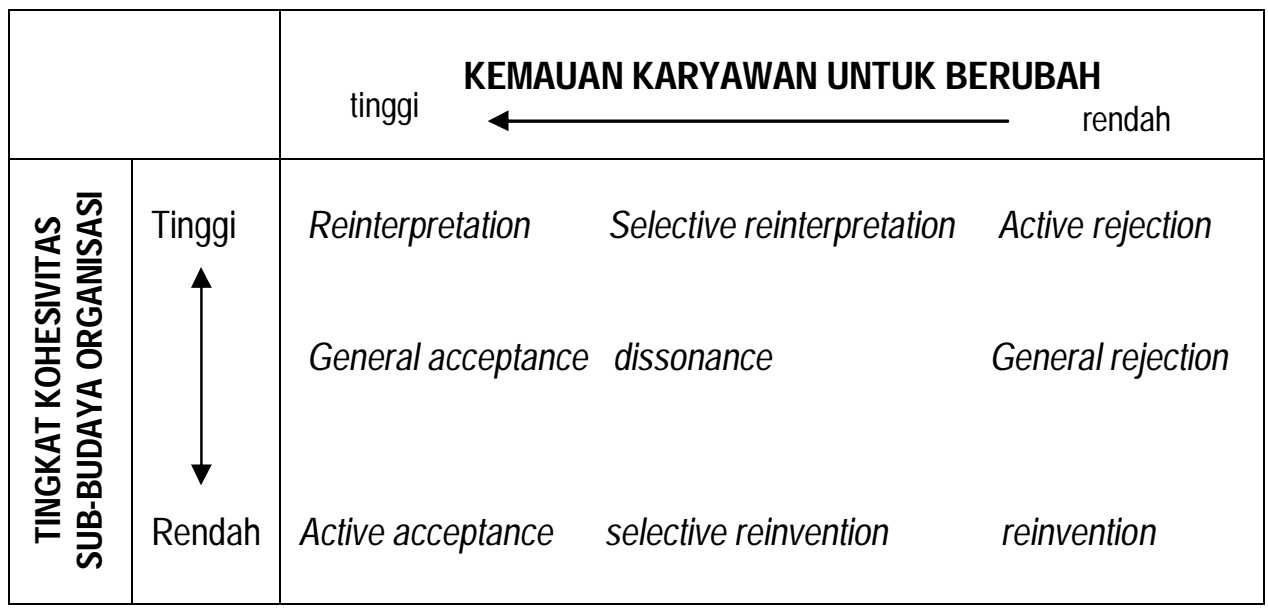

Sumber: Harris and Ogbonna, 1998, p. 81

\section{Gambar 2}

Respon Karyawan terhadap perubahan budaya organisasi

Gambar 2 menunjukkan sembilan kemungkinan respon karyawan terhadap perubahan budaya organisasi dilihat dari keinginan karyawan untuk berubah dan kuat tidaknya sub-budaya organisasi perusahaan. Pertama, karyawan menerima perubahan apa adanya (active acceptance). Di sini karyawan setuju untuk berubah, mau mengadopsi perubahan dan mau berpartisipasi dalam perubahan tersebut tanpa mempertanyakan apakah perubahan itu perlu atau tidak. Kondisi ini terjadi ketika karyawan mempunyai kemauan yang tinggi untuk berubah dan di sisi lain kohesivitas subbudaya organisasi relatif rendah. Kedua, selective reintervention terjadi ketika kemauan karyawan untuk berubah moderat (tidak tinggi, tidak rendah) tetapi kohesivitas sub-budaya organisasi rendah. Selective reinvention bisa diartikan sebagai reaksi karyawan terhadap perubahan budaya dimana karyawan menunjukkan tendensi untuk mendaur ulang, secara selektif, beberapa elemen budaya yang sedang berlaku, seolaholah menjadi budaya baru. Jadi boleh dikatakan bahwa dengan Selective reinvention sebetulnya tidak ada perubahan yang berarti, kadang-kadang hanya artefak saja yang diubah/diberi label baru tetapi nilai-nilai organisasi 
yang menjadi inti budaya tidak berubah. Sementara itu respon ketiga disebut reinvention. Respon ini terjadi ketika kemauan karyawan untuk berubah dan kohesivitas sub-budayanya rendah. Reintervention bisa diartikan sebagai pura-pura menerima perubahan karena pada dasarnya tidak ada elemen budaya yang berubah. Budaya yang ada hanya ditata ulang seolah-olah membentuk budaya baru. Tidak seperti pada Selective reinvention yang mendaur ulang sebagian komponen budaya, pada reinvention pendauran ulang ini dilakukan secara menyeluruh. Jadi bisa dikatakan bahwa reinvention merupakan bentuk reaksi karyawan yang lebih radikal dibanding dengan selective reinvention.

Keempat, secara umum karyawan mau menerima perubahan (general acceptance) - terjadi karena kuatnya keinginan untuk berubah tetapi tingkat kohesivitas sub-budaya cenderung moderat. Dengan general acceptance karyawan mempunyai tendensi untuk menerima perubahan hanya terhadap sebagian komponen budaya karena pada dasarnya mereka tidak mau merubah penjiwaan mereka terhadap nilai-nilai dan keyakinan yang ada. Berbeda dengan Selective reinvention yang lebih mengandung unsur pandauran ulang budaya, general acceptance mengandung unsur menolak sebagian budaya yang ada terutama pada komponen luar budaya organisasi. Respon kelima disebut dissonance yakni ketika keinginan untuk berubah dan kehosivitas budayanya relatif moderat. Respon ini bisa diartikan sebagai a state of cognitive imbalance terjadinya ketidakseimbangan kognitif akibat adanya usaha perubahan budaya. Kondisi ini ditandai dengan kebimbangan karyawan antara menerima dan menolak perubahan dan tindakan-tindakan karyawan yang tidak konsisten. General rejection - penolakan secara umum adalah bentuk keenam dari respon karyawan terhadap perubahan budaya. Respon ini terjadi ketika keinginan untuk berubah rendah tetapi kohesivitas budaya moderat. Berbeda dengan general acceptance yang mau menerima perubahan meski tidak sepenuhnya, general rejection adalah secara umum menolak perubahan yang ditandai dengan adanya ketidakpercayaan karyawan terhadap pimpinan organisasi dan penolakan untuk mengadopsi budaya yang baru.

Ketujuh adalah reinterpretation. Terjadi jika keinginan berubah dan kohesivitas sub-budaya sama-sama tinggi. Reinterpretation bisa diartikan sebagai reaksi atas perubahan budaya yang ditandai dengan kecenderungan untuk menterjemahkan budaya yang baru dalam bentuk pengembangan nilai-nilai organisasi dan pola prilaku yang sesuai baik dengan budaya lama maupun budaya baru. Disini para karyawan akan berusaha untuk menyesuaikan prilakunya agar selaras dengan tujuan perubahan. Kedelapan, adalah respon yang terjadi jika keinginan karyawan untuk berubah moderat tetapi tingkat kohesivitas sub-budaya sangat tinggi. 
Respon ini disebut selective reinterpretation yang bisa diartikan sebagai reaksi perubahan yang melibatkan penolakan terhadap perubahan dan secara selektif melakukan reinterpretasi terhadap beberpa atribut budaya. Dibandingkan dengan reinterpretation yang cenderung merupakan tanggapan yang radikal, selective reinterpretation melibatkan beberapa perubahan saja. Terakhir, kesembilan, adalah active rejection yang terjadi jika keinginan berubah sangat rendah dan sebaliknya kohesivitas subbudaya yang ada sangat tinggi. Disini karyawan serta merta menolak perubahan budaya, baik cara yang digunakan maupun komponen budayanya. Active rejection dengan demikian merupakan kebalikan dari active acceptance dan oleh karenanya active rejective merupakan reaksi yang paling tidak diharapkan.

Untuk memperjelas uraian di atas, berikut ini disajikan ringkasan tentang respon karyawan terhadap perubahan budaya dan aspek-aspek perubahannya.

Gambar 3. Bentuk-bentuk reaksi perubahan dan aspek-aspeknya

\begin{tabular}{|c|c|}
\hline Bentuk tanggapan karyawan & Aspek-aspek perubahan budaya \\
\hline 1. Active acceptance & - Karyawan menerima apa adanya perubahan budaya \\
\hline Selective reinvention & $\begin{array}{l}\text { Secara selektif, karyawan mencoba mendaur ulang bebe- } \\
\text { rapa elemen budaya lama (seolah-olah) menjadi budaya } \\
\text { baru meski esensinya tidak ada perubahan, beberapa arte- } \\
\text { fak misalnya diberi label baru. }\end{array}$ \\
\hline 3. Reinvention & $\begin{array}{l}\text { Secara umum karyawan enggan melakukan perubahan, } \\
\text { Budaya lama, bukan hanya beberapa elemen, di daur ulang } \\
\text { seolah-olah membentuk budaya baru. }\end{array}$ \\
\hline 4. General acceptance & $\begin{array}{l}\text { Secara umum karyawan mau menerima perubahan meski } \\
\text { tidak sepenuhnya seperti pada active acceptance. Ada be- } \\
\text { barapa perubahan yang ditolak dengan asumsi budaya lama } \\
\text { masih ada yang cocok. }\end{array}$ \\
\hline 5. Dissonance & $\begin{array}{l}\text { Karyawan mengalami keraguan antara menerima dan } \\
\text { menolak perubahan. Hal ini ditandai dengan prilaku karya- } \\
\text { wan yang tidak konsisten. }\end{array}$ \\
\hline 6. General rejection & $\begin{array}{l}\text { Secara umum karyawan menolak perubahan meski } \\
\text { kemungkinan perubahan masih diterima dengan alasan bu- } \\
\text { daya lama tidak lagi kondusif dengan lingkungan baru. }\end{array}$ \\
\hline 7. Reinterpretation & $\begin{array}{l}\text { Secara umum karyawan mencoba menginterpretasikan } \\
\text { perubahan dan menyesuaikan diri, secara behavioral, de- } \\
\text { ngan perubahan tersebut. }\end{array}$ \\
\hline 8. Selective Reinterpretation & $\begin{array}{l}\text { Karyawan menginterpretasikan kembali beberapa kompo- } \\
\text { nen budaya dan nenolak sebagian komponen yang lain. }\end{array}$ \\
\hline Active rejection & Karyawan serta merta menolak perubahan budaya \\
\hline
\end{tabular}

Sumber: Ringkasan dibuat oleh penulis 
Menyadari bahwa tidak semua budaya cocok untuk semua lingkungan organisasi (Goffee and Jones: 1996) maka perubahan budaya mestinya merupakan hal yang biasa, bukan sesuatu yang harus diributkan ketika berlangsung privatisasi. Namun melihat bervariasinya tanggapan karyawan terhadap perubahan budaya organisasi yang paling ekstrim karyawan bisa menerima apa adanya perubahan budaya tanpa perlu menanyakan makna perubahan tersebut dan tidak mempersoalkan cara perubahannya, dan ekstrim yang lain, karyawan bisa meonlak sepenuhnya perubahan budaya organisasi, baik alasan maupun cara perubahannya seperti tersebut di atas, maka para manajer yang terlibat dan bertanggung jawab terhadap proses privatisasi harus mengantisipasi sejak awal kemungkinan adanya resistensi karyawan terhadap peru-bahan tersebut. Oleh karenanya sosialisasi terhadap perubahan ini merupakan upaya smoothing - mengurangi gejolak yang tidak bisa dihindarkan (Jones: 1986; Pascale: 1985) agar tidak terjadi apa yang disebut cultural shock (Hofstede: 1997). Bahkan upaya ini bisa dilakukan jauh sebelum keputusan privatisasi dibuat.

Dalam kaitannya dengan sosialisasi di atas, langkah penting pertama yang bisa dilakukan para manajer adalah mengaudit budaya yang sekarang ada (Thusman and O'Reilly III, 1997:122-128), dilanjutkan dengan mendefinisikan secara jelas budaya organisasi yang diharapkan (jika perlu perubahan budaya) dan diakhiri dengan sosialisasi budaya baru ke semua anggota organisasi dalam rangka menciptakan motivasi intrinsik. Seperti telah disebutkan dimuka tentang kompatibilitas hard system dan soft system tools, audit budaya dimulai dengan mengidentifikasi hard system toolnya yakni identifikasi tantangan strategis yang akan dihadapi perusahaan dimasa datang (setelah realisasi privatisasi). Identifikasi ini dianggap penting mengingat lingkungan perusahaan publik berbeda dengan lingkungan perusahaan swasta. Secara berturut-turut identifikasi ini akan menjadi prasyarat bagi pembentukan sistem nilai dan norma prilaku. Secara rinci tahapan audit budaya bisa dilihat pada Gambar 4.

Setelah dilakukan audit budaya barulah ditetapkan budaya organisasi yang cocok dengan lingkungan yang baru. Untuk tugas ini, maka manajer harus memposisikan dirinya sebagai leader ${ }^{7}$ sebab seperti yang dikatakan oleh Schein (1997) peranan leader sangat menentukan dalam penciptaan budaya baru, dan selanjutnya baik menggunakan mekanisme formal maupun informal budaya baru ini disosialisasikan ke semua anggota organisasi.

\footnotetext{
${ }^{7}$ Disini perlu ditegaskan bahwa pengertian manajer dan leader/pemimpin tidak sama. Manajer adalah orang yang bisa memerintah, mengarahkan dan meminta bawahannya untuk melakukan tugas-tugas organisasi, sedangkan pemimpin adalah orang yang dapat memberi inspirasi dan mempengaruhi prilaku pengikutnya/ orang lain untuk melakukan sesuatu tanpa orang lain tersebut merasa terbebani (untuk penjelasan ini lihat misalnya Kerin, Mahajan and Varadarajan: 1990)
} 
Gambar 4. Audit budaya

\begin{tabular}{|l|ll|}
\hline Langkah 1 & a $\begin{array}{l}\text { Identifikasikan tantangan strategis yang akan dihadapi perusahaan dimasa } \\
\text { datang }\end{array}$ \\
Langkah 2 & $\begin{array}{l}\text { aaitkan strategi yang telah ditetapkan di atas dengan tugas-tugas penting yang } \\
\text { harus dilakukan }\end{array}$ \\
Langkah 3 & $\begin{array}{l}\text { Identifikan nilai-nilai dan norma prilaku yang bisa membantu menyelesaikan } \\
\text { tugas-tugas penting di atas }\end{array}$ \\
Langkah 4 & $\begin{array}{l}\text { Lakukan diagnosis terhadap nilai-nilai dan norma prilaku yang sekarang ada } \\
\text { Langkah 5 }\end{array}$ & $\begin{array}{l}\text { Identifikasikan kemungkinan adanya kesenjangan antara nilai-nilai dan norma } \\
\text { prilaku yang ada dengan nilai-nilai dan norma prilaku yang disyaratkan }\end{array}$ \\
Langkah 6 & $\begin{array}{l}\text { Putuskan tindakan-tindakan yang perlu dilakukan untuk mempersempit/meng- } \\
\text { hilangkan kesenjangan di atas. }\end{array}$ \\
\hline
\end{tabular}

Sumber: Thusman and O'Reilly, p. 123

\section{PENUTUP}

Uraian di muka tentang implikasi privatisasi terhadap perubahan prilaku manusia dan budaya organisasi mengarahkan kita pada suatu kesimpulan sebagai berikut: Pertama, Jika selama ini para pengambil keputusan yang bertanggung jawab terhadap proses privatisasi cenderung lebih memperhatikan aspek finansial dan ekonomi sebagai variabel yang dianggap menetukan dalam keberhasilan privatisasi, paper ini melihat adanya dua aspek lain yang patut dipertimbangkan pula yakni aspek manusia dan kultural. Dasar pertimbangannya adalah privatisasi berarti perubahan organisasi dan perubahan itu sendiri tidak akan berhasil jika ada hambatan yang datang dari manusia yang terlibat didalamnya. Demikian juga, perubahan dikhawatirkan tidak akan berhasil jika kebiasaan manusia dan organisasi yang dikenal sebagai budaya organisasi tidak berubah.

Kedua, dari dimensi waktu, para pengambil keputusan perlu memperhatikan implikasi privatisasi terhadap kedua aspek ini - manusia dan budaya yakni implikasi jangka pendek dan jangka panjang. Dalam jangka pendek, privatisasi diperkirakan akan menyebabkan timbulnya rasa khawatir dan stress di kalangan para pegawai yang masih tinggal yang tentunya akan berdampak pula pada kepuasan kerja dan kinerja perusahaan. Secara gradual kekhawatiran dan stress ini akan berkurang bersamaan dengan berjalannya waktu ketika aturan main perusahaan mualai tertata dengan baik dan kekhawarian yang selama ini ditakutkan karyawan tidak terbukti. Disisi lain, meski dalam jangka kemungkinan perubahan budaya belum dirasakan oleh karyawan perusahaan, dalam jangka panjang karyawan kemungkinan akan menyadari bahwa dirinya harus mengikuti perubahan budaya sebagai konsekuensi terjadinya privatisasi. Perubahan 
ini dalam jangka panjang mungkin tidak dapat dihindarkan. Kesimpulan kedua ini dapat diringkas dalam matrik berikut ini:

\begin{tabular}{|c|c|c|}
\hline \multicolumn{2}{|r|}{ Jangka pendek } & Jangka panjang \\
\hline \multirow{2}{*}{ 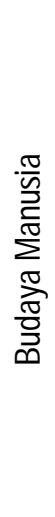 } & $\begin{array}{l}\text { - Meningkatnya tingkat kekhawa- } \\
\text { tiran karyawan } \\
\text { Karyawan cenderung mempunyai } \\
\text { pandangan negatif terhadap pe- } \\
\text { rusahaan } \\
\text { Meningkatnya stress } \\
\text { Meningkatnya ketidak puasan } \\
\text { kerja }\end{array}$ & $\begin{array}{l}\text { Berkurangnya tingkat kekhawati- } \\
\text { ran karyawan } \\
\text { Pandangan negatif mulai } \\
\text { berkurang } \\
\text { Kepuasan kerja meningkat } \\
\square \text { Kinerja perusahaan mulai mem- } \\
\text { baik }\end{array}$ \\
\hline & $\begin{array}{l}\text { Perubahan budaya belum dirasa- } \\
\text { kan oleh seluruh anggota orga- } \\
\text { nisasi }\end{array}$ & $\begin{array}{l}\text { Perubahan budaya tidak dapat } \\
\text { dihindarkan, berhasil tidaknya } \\
\text { privatisasi bergantung pada } \\
\text { reaksi karyawan dan kuat tidak- } \\
\text { nya budaya lama }\end{array}$ \\
\hline
\end{tabular}

Kesimpulan ini sesungguhnya lebih tepat disebut sebagai sintesa dan oleh karenanya perlu dukungan bukti-bukti empiris melalui penelitian lebih lanjut. Dengan metode penelitian longitudinal yang dibarengi dengan analisis kualitatif dan kunatitatif, diharapkan sintesa di atas bisa dibuktikan secara empiris dan disisi lain pengembangan teori tentang perubahan sebagai akibat privatisasi bisa dikembangkan.

\section{DAFTAR PUSTAKA}

Achmad Sobirin (1997), Organizational Culture of Selected Catholic and Islamic Universities: A Comparative Study, Unpublished Dissertation, University of Santo Tomas, Manila, Philippines.

Achmad Sobirin (1999), Memahami Arti dan Makna Budaya Organisasi, Jurnal Sinergi, Vol. 2 no. 2 Magister Manajemen UII, hal. 189-215

Anonymous (1994) Privatization and the Private Sector, Corporate Finance. Jan, 110, pp. 43-44.

Anonymous (1999), Philippines Issues Market Duo, Euroweek ${ }_{\perp}$ Feb 12, n589, p. 15

Anonymous (1998), Thailand: Thai Privatization Framework for Ratchaburi Power Plants,_East Asian Executive Reports. Aug 15; v20n8, p. 23

Bate, P. (1994), Strategi for Cultural Change, London: Butterworth Heinemann 
Barlett, C.A and S. Ghoshal (1994), Changing the Role of Top management: Beyond Strategy to Purpose, Harvard Business Review, November-December, pp. 79-88

Beyer, J.M. and H.M. Trice (1987), How An Organization Ritual Reveals Its Culture, Organizational Dynamics,_15, (Spring), pp. 5-24.

Butler, R. (1991), Designing Organizations: A Decision Making Perspective, London: Routledge

Cartwright, S. and C.L. Cooper (1993a), The Role of Culture Compatibility in Successful Organizational Marriage, Journal of Management Executive, May; 7(2), pp. 57-70.

Cartwright, S. and C.L. Cooper (1993b), Of Mergers, Marriage and Divorce: The Issues of Staff Retention, Journal of Managerial Psychology. 8(6), pp. 7-10.

Cartwright, S. and C.L. Cooper (1995), Organizational Marriage:"Hard" versus "Soft" Issues? Personnel-Review. 24(3), pp. 32-42

Cherrington, D.J. (1992), Organizational Behavior ${ }_{1}$ Allyn and Beacon

Cunha, R.C.E., and C.L. Cooper (1998), Privatization and Human Factor, Journal of Applied Management Studies, December, pp.201-210.

Davis, S. (1984), Managing Corporate Culture ${ }_{1}$ Cambridge, MA: Belinger

Dees, J.G. (1998), Enterprising Nonprofits, Harvard Business Review January-February, pp.55-67.

Fieser, J. (1996), Do Business Have Moral Obligations Beyond What the Law Requires?, Journal of Business Ethics, 15, pp. 457 - 468

Gagliardi, P. (1986), The creation and Change of Organizational Culture: A Conceptional Framework, Organization Studies,_Vol. 7, no. 2, pp.119-134

George, M.J. and G.R. Jones (1999), Understanding and Managing Organizational Behavior, $2^{\text {nd }}$ edition, Reading, Mass: Addison Wesley Pub. Co. Inc.

Ghoshal, S. and C.A. Barlett (1995), Changing the Role of Top Management: Beyond Structure to Process, Harvard Business review, January-February, pp. 86-96.

Goffee, R and G. Jones (1996), What Holds the Modern Company Together?, Harvard Business Review, Nov. - Dec., pp. 133-148. 
Gregory, K.L. (1983), Native View paradigms: Multiple Cultures and Culture Conflict in Organization, Administrative Science Quarterly, 28, pp. 359-376

Harris, L.C, and E. Ogbonna (1998), Employee Responses to Cultural change Efforts, Human Resource Management Journal, Vol. 8 No. 2, pp. 78-92.

Hatch, J.M. (1993), The Dynamics of Organizational Culture, Academy of Management Review, October, Vol. 18, no. 4, pp. 657-693.

Hawkin, P. (1997), Organizational Culture: Sailing between Evangelism and Complexity, Human Relation, April, Vol. 50, no. 4, pp. 417-440.

Hofstede, G. (1980), Culture's Consequencies: International Differences in Work Related Values ${ }_{1}$ Sage Publications.

Hofstede, G. (1997), Cultures and Organizations: Sofware of the Mind ${ }_{2}$ New York: McGraw Hill

Hofstede, G., B. Neuijen, D. Ohayev, and G. Sanders (1990), Measuring organizational Culture: A Qualitative and Quantitative Study Across Twenty Cases, Administrative Science Quarterly ${ }_{2}$ June, pp. 286-318

Hennessey Jr., J.T. (1998), "Reinventing" Government: Does Leadership Make the Difference? Public Administration Review ${ }_{2}$ Nov/Dec., 58(6), pp. 522-532.

Iverson, R.D. (1996), Employee Acceptance of Organizational Change: The Role of Organizational Commitment, The International Journal of Human Resource Management,_February, pp.122-149.

Jones, G. (1986), Socialization Tactics, Self-Efficacy, and Newcomers' Adjustments to Organizations, Academy of Management Journal, 29,2, pp. 262-279.

Kerin, R.A., V. Mahajan and P.R.Varadarajan (1990), Contemporary Perspectives on Strategic Market Planning, Boston: Allyn and Bacon.

Kluckhohn, F. and F. Strodtbeck (1961), Variation in Value Orientation ${ }_{1}$ Wesport, CT: Greenwood Press

Kotter, J.P. and J.L. Heskett (1992), Corporate Culture and Performance, New York: The Free Press

Leadford Jr., G.E., J.R. Wendenhof and J.E. Strahley (1995), Realizing a Corporate Philiosophy, Organization Dynamics, 23 (Winter), pp. 4-19 
Marchington, M; A. Wilkinson; P. Ackers and J. Goodman (1994), Understanding the Meaning of Participation: View from the Workplace, Human Relation, August, 47(8), pp: 867-894

Martin, J., M.S. Feldman, M.J. Hatch and S.B. Sitkin (1983), Uniqueness Paradox in Organizational Stories, Administrative Science Quarterly, 28, pp. 438-453

Martin, J. and M.E. Powers (1993), Organizational Stories: More Vivid and Pervasive than Quantitative Data, in B.M. Staw (ed.) Psychological Dimension of Organizational Behavior, New York: Macmillan Publishing Company, pp.258-266

M. Natzir Said (1985), Perusahaan-Perusahaan Pemerintah Indonesia, Bandung, Penerbit Alumni.

Mesch, D.J., J.H. McGrew, B.A. Pescosolido, and D.F. Haugh (1999), The Effect of Hospital Closure on Mental Health Workers: An Overview of Employment, Mental and Physical Health, and Attitudinal Outcomes, Journal of Behavioral Health Services and Research, August, 26 (3), pp. 305-317

Mirsha, K.E., G.M. Spreitzer, and A.K. Mirsha (1998), Perserving Employee Morale during Downsizing, Sloan Management Review, Winter, pp. 83-95.

Morgan, G. (1996), The Images of Organization, London: Sage Publications.

Nijhof, A. and O. Fisscher (1997), Dealing with Ethical Dillemmas in Organizational Change Processes, International Journal of Value Based Management, 10, pp. 173-192

Pascale, R. (1985), The Paradox of "Corporate Culture": Reconciling Ourselves to Socialization, California Management Review, 27,2, pp. 26-41

Peters, K. (1999), Down to the Core, Government Executive, May, 31(5), pp. 20-28.

Pheysey, D.C. (1993), Organizational Cultures: Types and Transformations, London: Routledge

Poepowardojo, S. (1989), Strategi Kebudayaan: Suatu Pendekatan Filisofis, Jakarta: Gramedia

Rama, M. (1999), Public Sector Downsizing: An Introduction, The World Bank Economic Review, January, 13(1), pp. 1-22. 
Reynolds, P.D. (1986). Organizational Culture as Related to Industry, Position and Performance: A Preliminary Report, Jurnal of Management Studies, 23, pp. 333-345

Robbins, S.P. (1997), Organizational Behavior: Concept, Controversies and Applications $_{1} 6^{\text {th }}$ edition, Englewood Cliffs, NJ: Prentice Hall Inc.

Sathe, V. (1985), Culture and Related Corporate Reality,_Homewood, III: Richard D. Irwin.

Schein, E.H. (1983), The Role of the Founder in Creating Organizational Culture, Organizational Dynamics 12 (1), pp13-28.

Schein, E.H. (1984), Coming to a New Awareness of Organizational Culture, Sloan Management Review_Vol. 25. No 2 pp. 3-16

Schein, E.H. (1985), Organizational Culture and Leadership, San Fransisco: Jossey-Bass.

Schein, E.H. (1990), Organizational Culture, American Psychologist, February, pp. 109-119

Schein, E.H. (1997), Organizational Culture and Leadership ${ }_{2}$ San Fransisco: Jossey-Bass.

Thurow, L. (1996), The Future of Capitalism, London: Nicholas Brealy Publishing Ltd.

Thusman, M.L. and C.A. O'Reilly III (1997), Winning through Innovation, Boston Ma: Harvard Business School Press.

Trice, H.M and J.M. Beyer (1984), Studying Organizational Culture through Rites and Ceremonials, Academy of Management Review, 9, pp653-669

Wilkin, A.L. and W.G. Ouchie (19983), Efficient Culture: Exploring the Relationship between Culture and Organization Performance, Administrative Science Quarterly, 28, 468-481 